\title{
THE HISTORIAN AND THE MYTH OF THE "OBJECTIVE CAMERA:" A CRITIQUE OF FILM REALITY
}

\author{
Michael T. Isenberg \\ University of Nebraska at Omaha
}

As film becomes a commonplace teaching tool in history classrooms and as historians begin to turn to the film record in search of evidence, the educational and scholarly impact of films of reality broadens and deepens. It seems pertinent to offer a few observations concerning films of reality (or "factual" films), since this type of film is liable to be abused as both teaching tool and evidence by those maware of its limitations.

A curlous misapprehension long has existed concerning films that claim to depict reality. The idea that reality is capable of film representation is as old as the genre of film itself. So is the notion that such films may by neatly divided into categories such as "propaganda" and "non-propaganda," "fiction" and "non-fiction," or "factual" and "non-factual." This is due largely to a confusion which too readily relates films of reality to reality itself. Film content in this facile sense constitutes "truth"-a tragic and misleading truth since, as Virginia Woolf observed, a movie "can say everything before it has anything to say."1

Much time has been wasted trying to define boundaries between the "propaganda" film, the "educational" film, the "scientific" film, and other equally vague areas of cinema. If one regards propaganda as the "organized dissemination of interested information" which shows the "good side of one side of the question and the bad side of the other sides," 2 one is forced to regard every motion picture, no matter what its degree of objectivity, as propaganda. There has been no feature film or documentary produced, to this writer's knowledge, that deals with a controversial situation in an "educational" as opposed to a "propagandistic" fashion. The classroom film will always parade as an educator; the teacher should see it as an advocate.

The motion picture camera is a mechanistic tool which, no matter what the intentions of its operator, restricts and distorts reality as defined by the human eye and mind. There are certainly films of greater or lesser degrees of subjectivity produced by the camera mechanism and by the people involved in the filmmaking process. But for the historian and the teacher of history the debate over the propagandistic nature of a specific film is largely irrelevant.

The main barrier in establishing this irrelevance 1 ies in the fact that film traditionally has been regarded by many as a moral weapon; that is, there are "good" films and "bad" films, according to the moralistic impulses of the viewer. 'The moralist thus welcomes what he regards as "good" propaganda and castigates the "bad" propaganda. A history class becomes an easy target for a teacher wishing to push a deeply felt moral point via the avenue of $\mathrm{film}$. As a counterexample, try showing The Plow That Broke The Plains and then arguing that the loss of topsoil in the Thirties was solely the result of the ignorance of farmers.

When the question of aesthetics intrudes into the definition of film realism, the waters are muddied further. 3 One is then faced with the problem of defining "propaganda art" and "escapist art." The deeper questions of reality and meaning cannot be answered by these semantic techniques, as the philosopher Abraham Kaplan glumly concluded. "In short," he summarized, "if we pose the question whether art is realistic or not, we can answer as we choose, yes or no."4 This ambiguity is merely a reaffirmation of the intense subjectivity of the filmmaking process and its product.

Films have the unconmon quality of not only reshaping realfty but of becoming reality themselves. They can become, in Daniel Boorstin's terminology, 
a "pseudo-event." In the darkened classroom, they may comprise a11 the rea1ity avallable, an they present this reality on the terms of their makers. Students are forced to take the camera eye as their eye, and the will of the filmmakers constantly impinges on their will. In the most common situation, where there exists no perceptible opposition to film content in the first place, the current of "reality" from communicator to audience flows smoothly and unimpeded. This lack of perceived alternatives handicaps effective teaching. Where some philosophic traditionalists would presuppose a structured picture of "reality" outside the range of a camera lens, teachers must cope with the fact that on film the image of this reality can never comprise the reality itself.

Thus in the broadest sense all film conspires, whether intentionally or not, to reduce the audience to ready acceptance of its message. The message may consist of entertainment, or reportage, or both; bias is nevertheless continually present, in greater or lesser degree. In assuming that all films concerning a specific subject present biases that may not even be central to the intended theme, the historian merely is admitting the subjectivity of the entire filmaking process and that of its products. Pictures of "reality" are not the only proper subjects of study. There are no such pictures--only images and illusions.

Aldous Huxley once remarked that the cinema could do one thing better than literature or the spoken drama: it could be fantastic. He hoped that this "super-realism" would co-exist with the realistic quality of film to provide variety and widen the film's potential. 6 Virginia Woolf was moved by the nostalgic qualities she found in old newsreels, yet she felt that abstractions and "some residue of visual emotion" might be the key to the future of the cinema. ${ }^{7}$ Gilbert Seldes, an eary prophet of the value of film to our culture, wrote approvingly of Woolf's opinions. 8 In the minds of all three--a11 come to the study of movies from some aspect of literary art-film stayed solidly anchored in "reality" while reaching out to achieve illusion, an effort that was aesthetically stimulating and completely necessary if it was to remain viable as an art form. In the work of more recent critics like Parker Tyler and Marshall McLuhan, film has raised anchor and now floats serenely in a dream-world where illusion is total and "reality" a myth. 9

Early filmgoers had no such analyses available, and neither do most students. Largely unaware of the distortion inherent in the movie camera, classroom audiences also are susceptible to the confusion arising between the photography and the written or spoken commentary that accompanies it. When Kenneth Boulding observed that "the image is universally affected with reality, "10 he was defining a problem that confronts all students examining early films and film audiences. In spite of the media sophistication of our younger generation, this problem relates to them as well. We know that films are not "real" in any concrete sense. "Yet we also have a strong inclination toward believing early audiences (and possible some present-day student audiences in particular) have regarded them as such, an inclination caused by weighing published accounts of audience reactions to "factual" films. Each member of the audience looks at the screen through his own preconstructed prism of reality, which tells him what is "true-to-life" and what is not. To speak of "fiction" and "fact" in this situation is again somewhat irrelevant, since these and like terms necessarily contain a high degree of subjectivity. On top of this the teacher places his constant opponent-his own subjectivity. Given these overlying and complex patterns which impede both analytical research and effective instruction, historians only create more myths for their students and themselves by emphasizing dichotomies where at best the dividing lines are obscure and at worst no such situation exists. 
Early critics often confused reality with the photography of reality. Many believed the chief value of the camera lay in the fact that it was a recording instrument. "Truth" was regarded as a readily perceptible commodity available to any film viewer with the sense enough to see it. It was deemed incontrovertible because it was visual, immediate, and afforded no alternatives. "The value of the moving picture as a means of agitating for the betterment of social conditions is self-evident," the early critic W. Stephen Bush proclaimed. "Nothing affects us more powerfully than the truth when it is preached in pictures."1l Technical improvements in the industry only enhanced the ability of film to depict reality, and hence to tell the "truth." As late as 1941, it was asserted that improvements in audio, such as volume, range, and direction, and even in smell, were an "advancement in realism" which carried the cinema to the "very door of reality."12

Because unexposed film was literally tabula rasa, it was conceived to be the perfect recorder, an honest and incorruptible spool of cellulotd which somehow operated independently of human beings. Bush put this notion into words, apropos of World War I:

The only real and incorruptible neutral in this war is not the type but the film. The moving picture camera is convincing beyond the peradventure of a doubt. As a means of enlightening the public as to the honest truth of the situation it is an invaluable instrument in the hands of any and all of the warring nations. It is utterly without bias and records and reports but does not color and distort.

The prohibition of the motion picture camera at the front is nothing less than a loss to civilization and an additional hindrance to peace. 13

Teachers should be aware that "truth" is helped along in many films by gentle and not-so-gentle fakery. For example, most viewers were unaware that some film reportage in the early years of World War I consisted of carefully engineered fakes. Producers used electrical charges, gunpowder, spring bayonets, and underground explosives to simulate combat on the western front. There fictions were pawned off on an eager public as "combat footage." 14 Even today, such technological devices as post-dubbing, while necessary for effective communication, sorely compromise the images of "truth" and "reality" presented to the student.

Indeed, for the impressionable student the gap between cinematic illusion and reality may be nonexistent. Even knowledgeable adults may confuse the two; consider the reaction of impresario D. W. Griffith when he visited the western front in 1918. To Griffith that war was deja vu; it took the shape of a spectacle on the level of Birth of a Nation or Intolerance, with one exception: it was not being directed by D.W. Griffith. Upon his return he unburdened himself to reporters:

All these things were so exactly as we had been putting them on in pictures for years and years that I found myself sometimes absently wondering who was staging the scene. Everything happened just as I would have put it on myself--in fact I have put on such scenes time and time again. 15

Griffith's comment carried the confusion between reality and illusion to its extreme but logical denouement. If images of the war could appear real to many at home, the war itself could appear as a bad dream to some 
participants and observers. Combatants often used this notion as a psychic crutch; when reality proved unbearable, it could be made bearable by converting it to illusion. This confusion demonstrates the myth of the objective camera; it destroys artificial barriers between film "fact" and film "fiction;" and it affords scholars the full play of their skills in analyzing the transmission of ideas, attitudes, and values via the cinematic experience. Skepticism in this area contains more than its usual virtue because, as a later critic bluntly put it, "the camera is a natural liar."16

Newsreels are an excellent device for introducing students to the visual representation of an era. Early newsreels continued the novelty of the very first films by showing events "as they happened" or staging the events after the fact and passing the staged version off as the real thing. They were oriented toward novelty and the bizarre. The newsreel pioneers believed themselves to be creating a new journalistic technique, as in part they were, although the subject matter admittedly comprised a less than thorough coverage of the news. 17

A modern scholar has defined a newsreel as a straightforward record of an event; ${ }^{18}$ while this may be theoretically useful, one would be hardpressed to find a newsreel that would fit such a description. But illusion for a considerable time was not part of the vocabulary of the newsreel. For over a decade following the first war, there was little debate concerning the nature of the new pictorial journalism. It was the "weekly newspaper of the screen," and the events it depicted were assumed to be "actual" and "important."19 A sophisticated reviewer admired the newsreels for their power to provide a "more complete catharsis than anything devised for the mind or imagination of Hollywood" through their ability to present the dramatic actualities of everyday life. 20

In 1926 the newsreel was at the peak of its reputation, a peak not matched until the rise of the "news feature" in the late Thirties. Its combined circulation was estimated to reach almost $90 \%$ of all American theaters. "In this film," enthused one admirer, "the universe was turned back and yesterday seen. The news film has come to be the greatest historian of a11."21 Newsreel theater chains were functioning by 1931 . The vision of the pioneers had been realized; the newsreels were accepted by press and public alike as a valid form of journalism. One newsreel man remarked in 1938 that the newsreels were enjoying a prestige as extensive as it was deserved "for in them is seen not only swift and accurate representation of news but the closest approach to the ideal of genuine freedom of the press." 22

But doubt was growing. Perceptive critics began carefully to scrutinize content. Alexander Bakshy quietly suggested that newsreels could stand more imagination and intelligent selectivity of topics and less sensationalism. 23 Gilbert Seldes noted that about $10 \%$ of the newsreels he saw were really news; the rest were devoted to "features." Further, post-commentary (a necessary addition, given the existing state of film technology) seemed to destroy the spontaneity of the event. To Seldes newsreels were pictorially accurate, "but the tone becomes entirely false." 24 What news there was often appeared to be trivial in the extreme. "The peacetime newsreel," documentary pioneer John Grierson acidly remarked, "is just a speedy snip-snap of some utterly unimportant ceremony."25 By the end of World War II, newsreels had been clearly and correctly identified as being composed largely of superficial and escapist material.26

Chief among the successes in the film journalism field was the muchpraised March of Time. In 1938 it went to 11,000 theaters in thirty-five 
countrles. It was 1ively, entertaining, and due to the devotion and skill of its camera crews covered far more "news" than did its competitors. But even the March of Time catered to overdramatization; its format necessarily led to oversimplifled presentations and shallow analyses. By the time of its demise in the fall of 1951, after over 160 issues, 1t nevertheless was regarded widely as the quintessence of f1lm journalism. 27 Even documentarists such as Grierson and Paul Rotha had given 1t high praise during 1ts 11fet1me.28

Newsreels and "news features" for their entire life span, which may be dated very roughly from about 1910 to the decade of the Sixtles, were ideal vehicles for the dissemination of biased information. The same totality of approach that governed any feature presentation, shutting out the options of the viewer, worked just as effectively in the newsreel. One does not have to be paranoid nor brand newsreel producers as Machiavellian (they were not, though some were not very bright) to reallze the highly selective nature of the "news" that appeared on the nation's screens. A study done in 1935 by college soclology students indicated that newsreels were in large part not news at all. The following is their classification of the contents of 307 items in forty-five newsreels:

Classification $\quad \underline{\text { Percent }}$

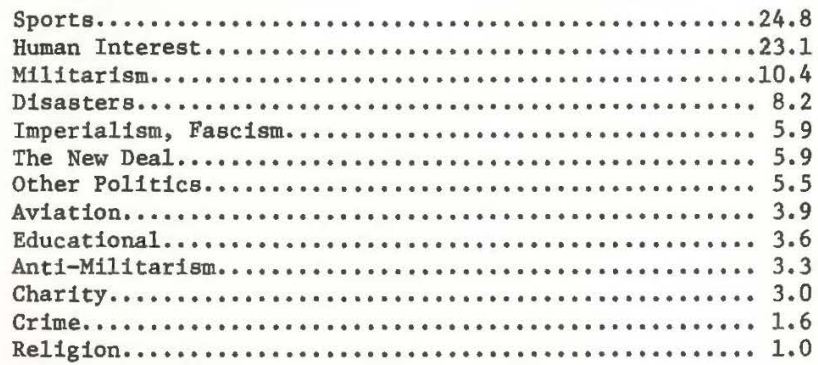

The study determined a "trend toward militarism and reaction."29 It is $\mathrm{sig-}$ nificant that at a time when America was semi-officially isolationist and professing 1tself thoroughly disgusted with the results of the Great War, "militarist" 1tems in 1 ts newsreels outnumbered "anti-militarist" 1tems three to one.

Newsreels, in spite of their disinterested and objective pose, were in many cases highly effective "propaganda" devices, especlally in view of the fact that audiences may have known of other alternatives to the film message recelved. The newsreel mode of presentation was particularly dangerous in a democratic society, not because of the trivialfty of the information conveyed, but because this information came to the viewer in the guise, whether intended or not, of comprising every aspect of the situation. Some newsreels were more blatant with this technique than others, with Hearst Metrotone News and Pathe News leading the list. The public could not know the machinations which determined what was photographed, much less how much of the photographed footage reached the screen and in what form. Parenthetically, the same situation applies today in the medium of television news. In this sense students should be reminded, as "TIME MARCHES ON," that they are watching historical evidence, not history.

The newsreel was in its day an admirable method for disseminating information in a mass society. But there was nothing admirable in its pose of disseminating ddsinterested information. The newsreel, 11ke the feature f1lm, was not reality. Its limited scope and method of approach were 
downplayed, wh1le the trite aphorism that "photographs don't $11 e^{\prime}$ remained the underlying justification for its popularity. Teachers of history, who may grant the newsreel a lesser measure of subjectivity than many other types of film, nevertheless should be prepared to accept newsreel situations as the contrivances they generally were. The situations were for the most part unposed, but editing, scripting, and dubbing mark points of contrivance. The Nation's pithy comment concerning newsreels should serve as a warning and is worth remembering: "Though photographs can't lie, 1lars certainly can photograph." 30

If the newsreel is bound by its format to stress spectacle and simplify complex themes, there remains a significant public for "longer films of reality." This public has been the target of the documentary movement. The baste suppositions of leading documentarists may be summarized as follows. The movie camera $1 \mathrm{~s}$ mobile and capable of reproductive art. The modern world In all 1ts complexity can best be presented, via this art, in 1ts natural setting. This means no actors, no staged scenes; everything must be "real." The force of this reality must be presented to the viewer by skillful editing. In editing 11es the key to the documentary art. It is that part of the process which most determines the shape of the flnal product.

The finished documentary film seeks to be both a "dramatic picture of reality" and a "social commentator. "31 Documentarists desire a fusion of informative material with dramatic technique. The constant aim is to make the documentary more "real" and "true to life." Richard McCann has noted what differentiates documentary from the feature f1lm; in general, the documentary "parallels the area of social studies."

It is subject matter, not method, that counts most in a documentary. It is integrity of purpose, bent upon authenticity of comment, which brings with it the desire to seek out real places and real people as means. It is characteristic of the cocumentary writer and producer. that they seek subjects for films which will cast $11 \mathrm{ght}$ on important public problems. This is the kind of civic responstbility which adds new dimensions to the artist's responsibility and makes documentary different. 32

Documentaries do not attempt that pose of complete 1mpartiality which cloaks the newsreel but, In Lloyd Ramseyer's words, they successfully create the "illusion of being an authentic representation of fact." 33 "In spirit they are halfway houses between the quasi-objective forms of film and the familiar dramatized feature. Since most documentaries have a generous input of social commentary, they are almost axiomatically biased. The successful documentary thus achieves its difficult aim of being informative, theatrical, and persuasive at the same time.

Since most American documentaries have attacked problem areas in society, either by contemporary filming or by the rearrangement of photographic records, they have tended to parade a decldedly liberal and reforming point of view. The historlan may thus be inclined to find himself a member of the audlence rather than a detached observer. This seductive notion is one measure of the power of "documentary realism." Film presented in this fashIon has an enormous capacity for creating sympathetic involvement.

Documentary films usually are subordinate to feature films in terms of audience appeal. Only during wartime do documentarles compete successfully for audience atfention. The natural drama of war is an irresistible topic for documentarists, perhaps too much so. The documentary film continually labors under the strain caused by dramatic needs on the one hand and the 
necessity for achieving realism on the other. The teacher must weigh his own classroom needs when selecting such a film. Those who select films sight unseen and become a first-time audience with their students seriously compromise their teaching role in an objective sense.

No film can masquerade as reality. Every non-feature film should be regarded as "interested propaganda" until circumstances prove otherwise. The camera eye is not the human eye, nor are the sensibilities of the lens human. But the camera product unavoidably appears in these "humanistic" guises after it passes through the heads and hearts of cameramen, editors, commentators, and so on. The newsreel, news feature, and documentary comprise some of the most enticing evidence which can confront the student of history. Everything is weighted toward the suspension of nonaesthetic criticism; in the absence of balancing evidence, the plea of the "neutral camera" to be believed is powerful and compelling. While no film is without a message, the message received by historians will not necessarily be that intended by the film-maker. Bias and imaginative content thus may be made to serve the causes of historical knowledge and the effective teaching of history, rather than to confound them.

\section{NOTES} 310.

1Virginia Woolf, "The Movies and Reality," New Republic, August 4, 1926 ,

${ }^{2}$ This definition follows that of Richard D. MacCann, "Documentary Film and Democratic Government: An Administrative History From Pare Lorentz to John Huston," unpublished Ph.D. dissertation, Harvard University, 1951, 1314. There are of course degrees of "goodness" and "badness." A complete discussion of public communication and propaganda is contained in pages 10-14.

${ }^{3}$ For an argument against the primary usage of aesthetic criteria in historical research involving film, see my "A Relationship of Constrained Anxiety: Historians and Film," The History Teacher, VI (August, 1973), 553-68.

${ }^{4}$ Abraham Kaplan, "Realism in the Film: A Philosopher's Viewpoint," Quarter1y of Film, Radio and Television, Summer, 1953, 383-84.

5aniel J. Boorstin, The Image: A Guide to Pseudo-Events in America (New York, 1964), 145. Boorstin presents the curious case of one who fully grasps the illusionary nature of the film ("the movie can [never] give us the nut of the matter"--148), yet he seems to feel that something (the nove1?) may eventually and totally delineate "reality."

6Aldous Huxley, "Where are the Movies Moving?," Essays New and 01d (New York, 1927), 220-27. Films of course may be realistic without being reality.

7 Woolf, "The Movies and Reality," 308-10.

${ }^{8}$ Seldes believed the movie "can be made great by ceasing to be realistic." "The Abstract Movie," New Republic, September 15, 1926, 95-96.

${ }^{9}$ See in particular Parker Tyler, Magic and Myth of the Movies (New York, 1947), and Marshall McLuhan, Understanding Media: The Exterisions of Man (New York, 1964), 283-96. Myron Osborn Lounsbury, "The Origins of American Film Crit1c1sm, 1909-1939," unpublished Ph.D. dissertation, University of Pennsylvania, 1966, 491, states the problem thus: "Should the primary attribute of the motion picture be described as 'the illusion of reality' or 'the illusion of reality?" Emphasis in original. 
10 Arbor, 1961), 166.

${ }^{11}$ W. Stephen Bush, "The Social Uses of the Moving Picture," Moving Picture World, Apri1 27, 1912, 305.

12 Orestes H. Caldwe11, "Realism in the Movies," Scribner's Commentator, Apri1, 1941, 95-98. 1617.

${ }^{13}$ W. Stephen Bush, "War Films," Moving Picture World, September 19, 1914,

14"Fake War Movies," Literary Digest, November 30, 1915, 1079. I have been unable to establish any meaningful percentage of fakes as opposed to actual war footage. For an assessment of fakery in British films of the period, see Penelope Houston, "The Nature of the Evidence," Sight and Sound, Spring, $1967,89-90$.

${ }^{15}$ Harry C. Carr, "Griffith, Maker of Battle Scenes, Sees Real War," Photoplay Magazine, March, 1918, 23.

${ }^{16}$ Newton E. Meltzer, "Are Newsreels News?," Hollywood Quarter1y, Apri1, $1947,270$.

${ }^{17}$ An excellent general history is Raymond Fielding, The American Newsreel, 1911-1967 (Norman, Oklahoma, 1972). For an entertaining 1ook at an early newsreel cameraman's experiences with Pathé News Weekly, see Fred J. Balshofer and Arthur C. Miller, One Reel a Week (Berkeley, 1967), 6873.

18 MacCann, "Documentary Film and Democratic Government," 79. Here I will offend purists by regarding the "newsreel" and the "news feature" as branches of the same reportorlal tree; I use the term "newsreel" in most instances to cover both.

${ }^{19}$ Davidson Poughey, The Film Industry (London, 1921), 50. See, for example, D.W. Griffith's comment that "the moving picture is simply the pictorial press." The Rise and Fall of Free Speech in America, pamphlet (Los Angeles, 1916), 19 .

20 William Troy, "Journey to the End," Nation, May 30, 1934, 630.

${ }^{21}$ Emanuel Cohen, "The Business of International News by Motion Pictures," Annals of the American Academy of Political and Social Science, CXXVIII (November, $\overline{1926)}, \overline{74-78 .}$ Cohen was editor-in-chief of Pathé News.

${ }^{22}$ Louis R. Reid, "Amusement: Radio and Movies," in Harold E. Stearns, ed., America Now: An Inquiry into Civilization in the United States (New York, 1938), 34 .

${ }^{23}$ Alexander Bakshy, "The News Ree1," Nation, January 8, 1930, 54. See also "Motion-Picture Newsreels," New Republic, April 1, 1931, 164-65. 96.

${ }^{24}$ Gilbert Seldes, "Newsree1s and Pictures," New Republic, March 11, 1931,

${ }^{25}$ Forsyth Hardy, ed., Grierson on Documentary, rev. ed. (Berkeley, 1966), 145. Grierson was no kinder to the commercial film. Excerpts of his criticism may be found in George Pratt, ed., Spellbound in Darkness: Readings in the History and Criticism of the Silent Film, II (Rochester, 1966), 358-81. 
26 Meltzer, "Are Newsreels News?" 272. The complete indifference displayed by some newsreel men toward the intelligence of their audience is indicated in John B. Kennedy, "News on the Ree1," Commentator, February, 1939, 42-47. Kennedy's decidedly pro-newsreel argument includes the statement that "when you complain that cliches recur too much in newsreels--remember that nine-tenths of the newsreel audience doesn't know and doesn't care what a cllché is as long as they understand it" (43). Further, "everything must be spotted for intensive story telling" (46). See also the 11vely and ancedotal account of a newsreel cameraman, Charkes Peden, Newsreel Man (New York, 1932), which unabashedly admits catering to the entertainment demands of the public.

27 The March of T1me in the strictest sense was not a newsreel at a11, but a news feature. Yet it was periodic, topical, current, and openly (as opposed to covertly) analytic. For information on and praise of the March of Time, see Edgar Anstey, "The Film as Document and News," National Board of Review Magazine, Apri1, 1938, 8-10; "Making the March of Time," 1 bid., November, 1938, 8-11; Raymond Fielding, "Time Flickers Out: Notes on the Passing of the March of Time," Quarterly of Film, Radio and Television, Summer, 1957, 354-61. A leftist critique of newsreels in general and of the March of Time in particular as "mouthpleces for monopoly capital" is Robert Stebbins and Peter E11is, "Are Newsreels News?," New Theater and Film, April, 1937, 12-15, 44-45. A balanced assessment that weighs news interpretation against strict presentation of news is William Troy, "Plctorial Journalism," Nation, February $20,1935,232$.

${ }^{28}$ See Hardy, Grierson on Documentary, 201, for Grierson's comments; also Pau1 Rotha, Documentary Film (New York, 1939), 49. Selected issues of the March of Time are in the Metropolitan Museum of Modern Art, New York C1ty; a file is in custody of Time-Life Films, Inc., New York City.

${ }^{29}$ Selden C. Menefee, "The Movies Join Hearst," New Republ1c, October 9, 1935, 241-42. Even allowing for errors in categorization and observation, these percentages seem to comprise a clear indictment of newsreel coverage. The government moved 1nto the newsreel business in 1936, tacitly recognizing the propaganda value of this mode of communication. "'Educationa1' Newsreels for WPA," Literary Digest, August 8, 1936, 32.

30"Are Newsreels News?," Nation, October 2, 1935, 370. Compare this comment with that of Meltzer, n. 16. Of course even unretouched photographs can lie, under the right condttions.

${ }^{31}$ Pau1 Rotha, "The Documentary Method in Brttish Films," Nationa1 Board of Review Magazine, November, 1937, 7. This section is based primarily on Hardy's edition of Grierson's writings and on Rotha, Documentary Film. For biographical material on Grierson, see Hardy, Grierson on Documentary, 13-39. Brltish documentarists such as Rotha and Grierson and Americans such as Robert Flaherty and Pare Lorentz learned much from one another's craftsmanship.

${ }^{32}$ MacCann, "Documentary F11m and Democratic Government," 87-88. Where MaCann stresses subject matter, I see editing as the more crucial aspect of decumentary production.

${ }^{33}$ L1oyd L. Ramseyer, "A Study of the Influence of Documentary Films on Soclal Attitudes," unpublished Ph.D. dissertation, Ohio State UnIversity, 1938, 13. 